\title{
Social Determinant Of Home Delivery Among Ever-Married Women In Khyber Pakhtunkhwa Pakistan
}

\author{
Hussain Ali \\ Department of Sociology \\ Abdul Wali Khan University
}

\begin{abstract}
The poor maternal health is one of the public health issues facing by rural women in Pakistan. There are various socio-demographic and cultural factors which confine women to domestic sphere. The main objective of this research is to study various social factors as determinants of home delivery among ever-married women in Khyber Pakhtunkhwa province of Pakistan. In the present study researchers used the quantitative research design in which the data are collected through household survey in the pakhtun society. The data is collected from 503 ever married women in District Malakand, from May $1^{\text {st }}$ to November $30^{\text {th }}, 2016$. The results show that nearly two third 62.3 percent men's are key decision makers about antenatal care utilization, more than third forth 76 percent of husbands are key decision makers about home delivery due to their women subordinate position within household. The researchers concluded that men are key decision makers and their decision affect women's maternal health care. In order to achieve Sustainable Development Goal No. 3, the study recommends mainstreaming women in the decision making process in domestic sphere as well as their involvement in decision making about accessing and utilizing of maternal health care services.
\end{abstract}

Keywords: Home Delivery, Men's Decision, Subordinate Position, Women.

$$
\begin{aligned}
& \text { تلخيص }
\end{aligned}
$$

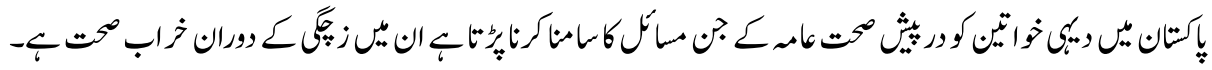

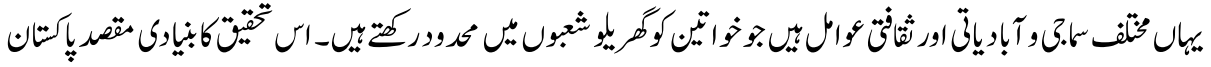

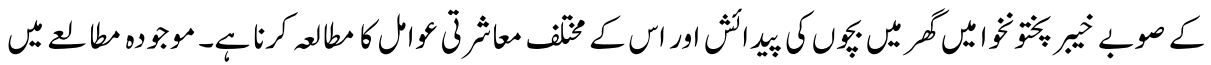

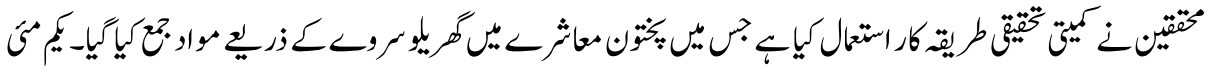

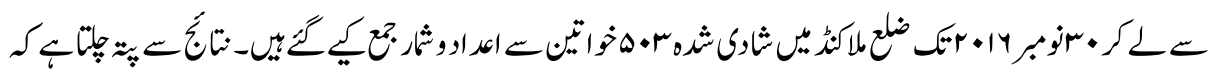

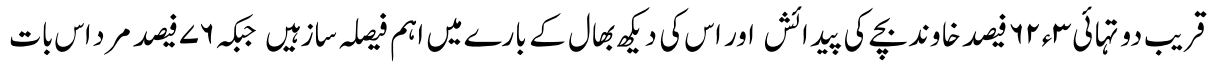

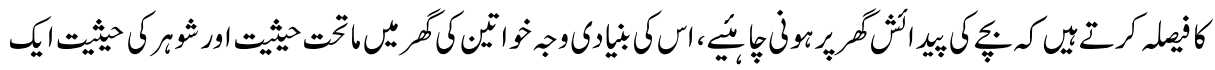

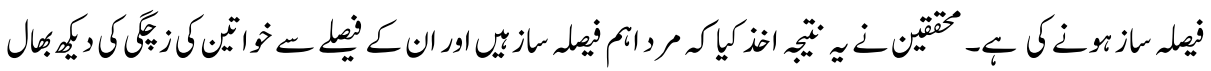

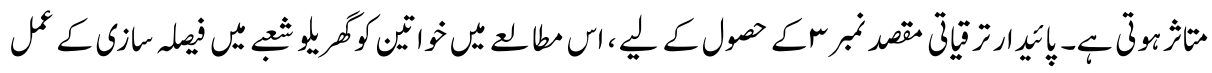




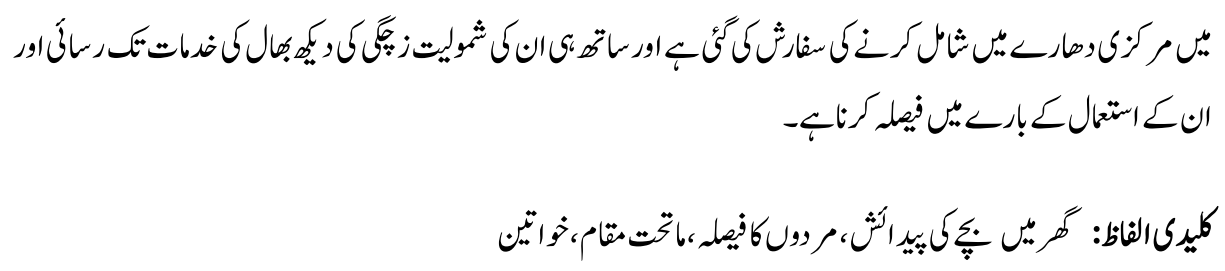

\section{Introduction}

Women's health refers to physical and mental health problems that are of exclusive concern for women, and which are more common in women or which differ in presentation, severity, or consequences in women compared to men (Kamimura, 2014; Ellsberg, 2008). Women's health is often defined in term of reproductive health and safety for younger women and in term of disease that appear in the female reproductive organs (Kilfoyle, 2016). According to World Health Organization (WHO) reproductive health is a state of complete physical, mental and social wellbeing and not merely the absence of disease or infirmity, in all matters relating to the reproductive system and to its functions and processes (Glasier, 2006). Reproductive health implies that people are able to have a satisfying and safe sex life and that they have the capacity to reproduce, and the freedom to decide if, when and how often to do so. Maternal health period is one of the health conditions in reproductive health process which is considered one of the risk times for women to survive. According to WHO maternal health is the health of a women during pregnancy, child birth and postpartum period (Thomas, 2014).

Poor maternal health is one of the fundamental public health issues facing by majority of the women in Pakistan (Bhutta, 2004). World Health Organization (WHO) estimated 358,000 women worldwide died due to poor maternal health. Similarly, WHO (2007) stated that maternal deaths are reported as 400/100,000 live births worldwide in which majority $(99 \%)$ are recorded from developing countries. Several research studies indicated that high maternal mortality is prevailing in Pakistan. It is found that during delivery a high number of women died due to delivery complication and poor utilization of the maternal health care services. The MMR in Pakistan is reported 276/100,000 live births among ever-married women (National Institute of Population Studies, 2013). According to State of World Population Report (2019), Maternal Mortality Rate (MMR) in Pakistan is $178 / 100,000$ live births. In the report it is statistically shown that almost fifty percent (48\%) of the births are not attended by skill health personnel in the country (UNFPA, 2019). It is found that maternal deaths proportion in the country is 500/100,000 live births. According to Pakistan Demographic and Health Survey (2018) still the 40 percent delivery are assisted by other than doctors (National Institute of Population Studies, 2019). More than fifty percent 52\% deliveries are reported in home as a place of delivery (National Institute of Population Studies, 2013). In the same report it is statistically shared that in the study area 60 percent of the home delivery are assisted by traditional birth attendant. 
There are several constraints identified in maternal health care among ever married women in developing countries. A wide range of research work highlighted the medical obstetric as a cause of poor maternal health among ever-married women. Mostly the researchers discussed the supply side barriers in access and utilization of maternal health care services (Fikree, 2004). Literature from developing countries highlighted that mostly the population are living in rural regions. They are kept within the four walls with limited decision making authority. Women are dependent on husband's income and financing (Bhutta, 2013; Mumtaz, 2009).

A study reveals that women are in subordinate position and having limited or no access to economic resources (Mahmood, 2002). Researches stated that women are not permitted to take individual decision about her health and place of delivery (Gabrysch, 2009). Women are inferior than men in the family and they are limited to private sphere. They are not allowed to visit a health facility without the consent and accompany of a male or elder women family member (Peters, 2008).

The Pakhtun women mobility in public sphere is not allowed by husband and other men headed household and they are engaged in day to day domestic work (Stephenson, 2006). Men are the only decision maker in public sphere mobility and access to public services in Pakhtun society. A recent study conducted in the area stated that women are living in the poor maternal health condition and they prefer to stay in home for treatment (Bhatti, 2002). In Pakistan women mobility are influenced by men's decision making. It is stated in researches that husbands with less education restrict their women mobility and compel women to home delivery (Sarker, 2016; Fikree, 2004). In developing countries various social factors are identified as influencing factors to poor maternal health care i.e restricted women mobility, limited decision making waiting to permission from husband on access to health facility and the consent of husband about the place of delivery (Ganle, 2016, 2015; Gupta, 2015).

Pakistani society is male dominant and the key decision makers in the family are men headed household. Research highlighted that woman subordinate position compels her to home delivery and maternal health services and care within home (Sarfraz, 2014).

It is very alarming situation highlighted by various researchers that women are restricted from visit alone to any health facility and they are not socially permitted by men headed household to spend money on her maternal health without the approval of her husband (Zanconato, 2006; Nyamongo, 2002). The main objective of this research is to study the social factors role in determining the home delivery among ever-married women in the study area. 


\section{Review of Literature}

According to World Health Organization definition the maternal mortality is the death of women during pregnancy or at the time of childbirth, or in 42 days after delivery. The cause of mortality is due to pregnancy or its management but not due to any incidental or accidental causes (Alkema, 2016). World literature statistically shown that globally the leading cause of women death is the complication during pregnancy and childbirth. Research studies highlighted that majority of the complication are preventable among pregnant women with timely intervention (Karlsen, 2011).

Many developing countries has made progress in reducing maternal mortality rate and improved access to health care facilities but still the majority of pregnant women deliver at home under the supervision of traditional birth attendant (Gabrysch, 2009).

The poor women health condition and gender discrimination in access to health facility in Pakistan is one of the major indicators which show a huge gender gap in the country. According to Global Gender Gap Index Report (2019) published by World Economic Forum, Pakistan on 151 positions in ranking of total 153 countries. The sub-index of Health and Survival Pakistan ranked at 149 out of 153 countries. It is also very alarming to mention that in South Asia region Pakistan is on the lowest position in ranking with 07 number and Bangladish on the top ranking in Global Gender Gap Index ranking by region, 2020 (World Economic Forum, 2019).

The health care access and utilization choice is one of the challenging determinants. There are different factors which are influencing the choice of accessing and utilization of maternal health care. These factors are including both the socio-cultural and accessibility. In many research studies it is highlighted that high MMR in the country is not only due to poor infrastructure, service delivery or supply side constraints rather the social circumstances, poor health policy, and its implementation are the major contributors to poor maternal health condition among pregnant women in the country (Lerberg, 2014).

Many social and behavioral scientist, and feminist working hard to realize the world that poor maternal health condition is not only a biological phenomenon rather women's health is directly influenced by social and cultural factors (Fosto, 2009). The social and behavioral scientist have long recognized that women's health problem must be understood as socially, culturally and economically produced. The feminist school view that women are oppressed in patriarchal social structure. Women are facing violence from their intimate partner and other male family members. They considered the gender as one of the main factor responsible for women poor health condition and discrimination in social setting (Das, 2013). Women in the study area are restricting from access and 
utilization of health care services from health facilities. They are dependent on men headed household decision and accompany to health facility. Mostly women are financially dependent on their men due to which they prefer to stay in home during maternal health period (Babalola, 2009).

Many researches highlighted the various barriers which are increasing the maternal mortality rate in developing countries. These barriers are included delay among pregnant women at home, insufficient time to reach the health facility for availing maternal health care services, non availability of transportation to facilitate pregnant women to health facility, mountains areas in rural setting, the financial dependency of on men headed household and cost of health care facility, women performance of defined gender role in domestic sphere, engagement in domestic workload, the fear of privacy and lack of confidence among pregnant women in health care facilities, and preference of traditional birth at home under the supervision of traditional birth attendant (King, 2015; Hogan, 2010). Along with the role of these factors many research studies focused that some demographic factors are also increasing the poor maternal health condition in developing countries. The demographic factors are included the current age of women, age at the time of marriage, her husband's age, the women and her husband level of education, family wealth, occupation of women and her husband, birth spacing in rural and urban setting. Many other studies observed that socio-cultural barriers are limiting the pregnant women accessibility to heath facility for antenatal care and delivery at health facility (Telfer, 2002). It is indicated in public health researches that mostly in rural setting in developing countries women are preferred to stay in home and take delivery services from illiterate and untrained traditional birth attendant. In Pakistan and other developing countries women are treated subordinate and their decision is very minimal in choosing a place for her health care services (Zakar, 2013). In Pakistani society particularly in rural setting the pregnant young women are discouraged to share their experiences about her pregnancy and the older women are considered as one of the major source of knowledge on the issue of maternal health and related experiences. Some other studies also highlighted the same factors responsible for poor maternal health care condition including lack of education among intimate partner, early marriage and early pregnancy, poor road and distance from mother child health care centers in rural areas in the country (Ali, 2016).

There are various models and theories are developed to understand health care utilization. These are included illness and medical case theory introduced by Suchman (Suchman, 1965) and the self help seeking theory developed by Mechanic (Mojtabai, 2002). Beside, the mentioned theories various models are also introduced to understand the health care utilization and accessibility. The models are included choice making model by Young's (Young, 1982), the health behavior model demonstrated by Andersen's (Andersen, 1995) and Thaddeus three delay model (Thaddeus, \& Maine, 1994). 
Researchers applied the three delay model in this research developed by Thaddeus. The model is contain three phases of delay. The first phase of delay is covering the women delay in decision to seek care. The delay is influenced by various factors including men's decision making, women low status, no knowledge about complication as outcome of pregnancy, acceptance of home delivery and considering the financial poor situation of the family. The second phase of the three delay model is delay in reaching care facility. This delay due to the factors of distance from health facility, transportation unavailability, poor infrastructure and most of the residence area is mountains. The third phase of the model covered the delay of receiving adequate health care. The responsible factors are poor medical facilities, untrained and non-serious health service providers. The referral mechanism is missing in the health facilities and the facilities are lacking to deal with pregnancy complication on emergency basis.

\section{Research Methodology}

Quantitative research design is applied in the present research study. The quantitative data were collected through interview schedule from ever-married women (15-49 years). In the present study researcher interviewed women permanently living in the study area and having a child birth in last 12 months. In the research study the data were collected from $\mathrm{n}=503$ respondent. The researcher translated the interview schedule to local language to collect data from the respondents. The present study was conducted in Malakand District Khyber Pakhtunhwa. Due to cultural sensitivity and women restriction in meeting with men in the society data were collected through Leady Health Visitors $(L H V S)$. Before field activity $L H V S$ were trained and orient about the research objectives and significance of the study. The verbal consent was taken from the respondent to ensure their privacy and confidentiality as written consent was not permitted by their men family members. The research was conducted in seven months from May 01 to November 30, 2016. In the research study dependent variable (home delivery) was measured by two categories health facility as a place of delivery which was coded as 01 and home delivery which was coded as 02 in the interview schedule. The independent variable in the present study was socio-demographic and cultural factors. The sociodemographic factors were measured with women education, husband education, women occupation, area of residence and women age. The cultural factors were measured with decision making in maternal health care access and utilization, decision making in family planning use, women position in the family, decision making in household purchase, decision making about place of delivery and decision making about public sphere mobility and intimate partner violence during pregnancy. SPSS software was used for data analysis and the researcher applied binary logistic regression to study the relationship between place of delivery as dependent variable and men's decision making as independent variable. In the present study delivery was measured with place of delivery while the men's decision making was measured from men's decision making 
about household purchase, access to maternal health care facility, to visits outdoor socialize and use of family planning methods.

\section{Ethical Consideration}

To make sure the confidentiality and privacy of the women the verbal inform consent is taken before the study. In the present research study data from women are collected through a research team comprised of women research assistant as male interaction with women in the study area is not permitted by the male headed household. There is no conflict of interest with the content of this research study.

\section{Results}

Table - 1

The association between socio-demographic factors and home delivery

\begin{tabular}{|l|c|c|c|c|}
\hline \multirow{2}{*}{$\begin{array}{l}\text { Socio } \\
\text { demographic } \\
\text { Variables }\end{array}$} & \multicolumn{2}{|c|}{ Place of Delivery } & & \\
\cline { 2 - 5 } $\begin{array}{l}\text { Respondent } \\
\text { Education }\end{array}$ & Health facility & Home & OR, 95\% C.I & $\begin{array}{c}\text { P. } \\
\text { Value }\end{array}$ \\
\cline { 2 - 5 } Illiterate & Frequency, \% & Frequency \% & & \\
\hline Educated & $63(24.2)$ & $196(92.0)$ & $36.052(20.368-$ & .000 \\
\hline Respondent age & $197(75.8)$ & $17(8.0)$ & 1.00 & \\
\hline Less than 30 years & $125(48.6)$ & $76(35.8)$ & 1.00 & \\
\hline $\begin{array}{l}30 \text { years and above } \\
\text { Husband's } \\
\text { Education }\end{array}$ & $132(51.4)$ & $136(64.2)$ & $1.695(1.168-2.459)$ & .005 \\
\hline $\begin{array}{l}\text { Illiterate } \\
\text { Educated }\end{array}$ & $47(18.1)$ & $102(47.9)$ & $4.164(2.751-6.305)$ & .000 \\
\hline $\begin{array}{l}\text { Respondent } \\
\text { residence }\end{array}$ & $213(81.9)$ & $111(52.1)$ & 1.00 & \\
\hline Plain & & & & \\
\hline Mountains & $185(85.3)$ & $207(77.2)$ & 1.00 & \\
\hline $\begin{array}{l}\text { Respondent } \\
\text { Occupation }\end{array}$ & $32(14.7)$ & $61(22.8)$ & $1.704(10.63-2.730)$ & .027 \\
\hline Employment & $87(33.5)$ & $19(8.9)$ & & \\
\hline House wife & $173(66.5)$ & $194(91.1)$ & $5.135(3.001-8.785)$ & .000 \\
\hline
\end{tabular}


Table no. 01 statistically indicated the correlation between demographic variables and home as a place of delivery among ever-married women in the research area. It is found in the results that women with less or no education attended by TBA and their delivery recorded in home as a place of delivery $(92.0 \%$ vs. $24.2 \%)$ with educated women delivery reported in hospital as a place of delivery. The OR of uneducated ever-married women is 36.052 time higher as compare to women with secondary and higher education in the research area (OR 36.052, CI 95\% 20.368-63.814). The above results highlighted that ever-married women education level is significantly in correlation with home as a place of home delivery ( $\mathrm{P}$ - value .000). In the above table ever-married women age is found significantly in differences with home delivery. The women with age of 30 or more years prefer to stay in home and attended by TBA (64.2\% vs. 51.4\%) in comparison with the same age women delivery in hospital. With the application of binary logistic regression the OR of women with 30 years and above is 1.695 times higher than less than 30 years of age among married women with pregnancy and delivery (OR 1.695, CI 95\% 1.168-2.459). It is significantly found in correlation between the women age and home delivery (P-value .005).

The above table statistically indicated that husband's literacy among the ever-married women is importantly in correlation with place of delivery. It is found that husband's illiteracy is greatly influencing the home delivery among married women $(47.9 \%$ vs. $18.1 \%$ ) as compare with the hospital delivery. In binary logistic regression the OR of illiterate husband in correlation with home as a place of delivery is 4.164 times higher than husband's education and hospital is a place of delivery (OR. 4.164, CI 95\% 2.7516.305). The results indicated that husband's education is significantly in correlation with home as a place of delivery (P-value .000). Place of delivery and area of residence are found in strong correlation. The women living in hard, rural and mountains are prefer to stay in home as a place of delivery $(22.8 \%$ vs. $14.7 \%)$ while the ever-married women living in urban, plan and settled areas are prefer to delivery attended by doctor in hospital. The OR of women living in rural, hard and mountains area is 1.704 times higher than women living in urban and plan areas (OR. 1.704, CI 95\% 10.63-2.730). The correlation is found significant between home as a place of delivery and mountains residence area of ever-married women (P-valve .027). In the table it is shown statistically that women staying in home and they are spending their lives within the four walls without their engagement in public sphere as employee is found significant with home delivery $(91.1 \%$ vs. $66.5 \%$ ). The OR of women living in houses without public sphere engagement is 5.135 times higher as analyzed with the comparison of employed women in public sphere (OR. 5.135, CI 95\% 3.001-8.785). The significance is recorded between women employment and home as a place of delivery (P-value .000). 
Table -2

The association between decision making and home delivery

\begin{tabular}{|c|c|c|c|c|}
\hline \multirow{3}{*}{$\begin{array}{l}\text { Decision making } \\
\text { authority }\end{array}$} & \multicolumn{2}{|c|}{$\begin{array}{l}\text { Place of delivery } \\
\end{array}$} & \multirow{3}{*}{ OR, 95\% C.I } & \multirow{3}{*}{$\begin{array}{c}\text { P. } \\
\text { Value }\end{array}$} \\
\hline & \multirow{2}{*}{\begin{tabular}{|c|}
$\begin{array}{c}\text { Hospital } \\
\text { facility }\end{array}$ \\
Frequency, \% \\
\end{tabular}} & \multirow{2}{*}{$\begin{array}{c}\text { Home } \\
\text { Frequency } \% \\
\end{array}$} & & \\
\hline & & & & \\
\hline \multicolumn{5}{|c|}{ ANC decision maker } \\
\hline Husband & $94(43.3)$ & $167(62.3)$ & $\begin{array}{c}2.164(1.502- \\
3.116)\end{array}$ & .000 \\
\hline Jointly & $123(56.7)$ & $101(37.7)$ & 1.00 & \\
\hline \multicolumn{5}{|l|}{$\begin{array}{l}\text { Place of delivery } \\
\text { decision }\end{array}$} \\
\hline Husband & $131(64.2)$ & $198(76.4)$ & $\begin{array}{c}1.809(1.206- \\
2.713)\end{array}$ & .004 \\
\hline Jointly & $73(35.8$ & $61(23.6)$ & 1.00 & \\
\hline \multicolumn{5}{|c|}{$\begin{array}{l}\text { Public sphere } \\
\text { engagement decision }\end{array}$} \\
\hline Husband & $140(64.5)$ & $238(88.8)$ & $\begin{array}{l}4.363(2.725- \\
6.986)\end{array}$ & .000 \\
\hline Jointly & $77(35.5)$ & $30(11.2)$ & 1.00 & \\
\hline \multicolumn{5}{|c|}{$\begin{array}{l}\text { Family planning } \\
\text { utilization decision }\end{array}$} \\
\hline Husband & $50(26.5)$ & $90(39.3)$ & $\begin{array}{c}1.800(1.185- \\
2.734) \\
\end{array}$ & .006 \\
\hline Jointly & $139(73.5)$ & $139(60.7$ & 1.00 & \\
\hline \multicolumn{5}{|l|}{ Women status } \\
\hline Inferior than men & $139(64.1)$ & $216(80.6)$ & $\begin{array}{c}2.331(1.546- \\
3.514)\end{array}$ & .000 \\
\hline Equal to men & $78(35.9)$ & $52(19.4)$ & 1.00 & \\
\hline \multicolumn{5}{|l|}{ IPV } \\
\hline Yes & $90(42.3)$ & $175(66.0)$ & $\begin{array}{c}2.657(1.831- \\
3.856) \\
\end{array}$ & .000 \\
\hline No & $123(57.7)$ & $90(34.0)$ & 1.00 & \\
\hline
\end{tabular}

The above table 02 shows the correlation between women position and place of delivery among ever-married women in the study area. It is found in the statistics that men are the key decision maker about women access and utilization of ANC services in the study area $(62.3 \%$ vs. $43.3 \%)$. Men decision influence the place of delivery and women are preferred to stay in home during pregnancy and attended by TBA. The binary logistic regression shows that the OR by husband decision making is 2.164 times higher than women decision making or joint decision making by husband and wife (OR 2.164 CI 95\% 
1.502-3.116). The correlation found significant between husband's decision making and home delivery among married women in the research area (P- valve .000). The correlation (76.4\% vs. $64.2 \%)$ is found significant between the husband's decision to choose home as a place of delivery in comparison with joint decision making in the family. Mostly in the study area women are subordinate and compelled to obey the decision of her husband. Therefore women prefer to deliver in home as compare to hospital as a place of delivery. The binary logistic regression result shows that OR of husband's decision is 1.809 times higher than women individual or joint decision with her husband. It is found that the correlation between husband's decision and home as a place of delivery is significant (P-valve .004).

Women public sphere mobility is influenced by husband's decision. Husband's decision restricts women from outer mobility including hospital delivery. It is shown in the statistics that husband's decision about home delivery is higher than women institutional delivery $(88.8 \%$ vs. $64.5 \%)$. The regression results indicated that OR of husband's decision about outer mobility and institutional delivery is 4.363 times higher than decision taken by jointly or only by ever-married women in the study area (OR 4.363, CI 95\% 2.725-6.986). The statistical significant association is found between husband's outer mobility decision and home delivery among ever-married women (P-valve .000). In the study area it is found that husband restrict women from utilization of family planning services. It is statistically shown that husband's who decide about the utilization of family planning services the women restricted to home delivery and they are recorded with unintended pregnancies. Among the ever-married women home delivery is higher than hospital as a place of delivery with husband decision about family planning utilization (39.3\% vs. $26.5 \%)$. The regression results indicated that OR are 1.800 times higher among the women with home delivery due to husband's decision making about family planning (OR 1.800, CI 95\% 1.185-2.734). The significant correlation is found between husband's family planning decision making and home delivery among ever-married women (P-valve .006).

In pakhtun society women are considered inferior in household position and in relationship with husband in the family. They are restricted from public sphere engagement due to their subordinate position. It is found that women with their inferior position than husband prefer to stay in home and take home delivery (80.6\% vs. $64.0 \%)$ against the hospital delivery. The regression results highlighted that OR of women inferior position and correlation with home delivery are 2.331 times higher than women with equal or superior position than husband in the family (OR 2.331, CI 95\% 1.5463.514). The association between women status in family and home delivery is highly significant (P-valve .000). Women are facing Intimate Partner Violence (IPV) in the study area. It is shown that pregnant women demand for access and utilization of maternal health care services available in the area are influenced by her husband's 
decision. When a women demand for outer mobility and health care services they are facing physical and sexual violence from husband. The women with IPV delivery in home is higher $(66.0 \%$ vs. $42.3 \%)$ than women delivery in hospital. The statistical test shown IPV is 2.657 times higher among women with home delivery than institutional delivery. The association is highly significant (P-valve .000).

Table -3

Pareson correlation matrix for Socio-demographic factors and decision making authority

\begin{tabular}{|c|c|c|c|c|c|c|c|c|c|c|}
\hline Variables & 1 & 2 & 3 & 4 & 5 & 6 & 7 & 8 & 9 & 10 \\
\hline $\begin{array}{l}\text { Home } \\
\text { Place of } \\
\text { delivery }\end{array}$ & 1.000 & .076 & $-.534^{* *}$ & $-.337^{* \pi}$ & $.367^{* \pi}$ & $-.238^{* *}$ & $-.151^{* *}$ & $-.147^{* *}$ & -.236 & $-.191^{* \pi}$ \\
\hline $\begin{array}{l}\text { Women } \\
\text { age }\end{array}$ & - & 1.000 & $-.119^{* *}$ & $-.130^{* *}$ & .003 & -.048 & -.005 & -.006 & -.017 & -.013 \\
\hline $\begin{array}{l}\text { Women } \\
\text { education }\end{array}$ & - & - & 1.000 & $.475^{* *}$ & $-.605^{* *}$ & $.331^{* *}$ & $.246^{* *}$ & $.240^{* *}$ & $.495^{* *}$ & $.214^{* *}$ \\
\hline $\begin{array}{l}\text { husband } \\
\text { education }\end{array}$ & - & - & - & 1.000 & $-.351^{* *}$ & $.294^{* *}$ & $.135^{* *}$ & $.123^{* *}$ & $.260^{* *}$ & $.089^{*}$ \\
\hline $\begin{array}{l}\text { Women } \\
\text { Occupation }\end{array}$ & - & - & - & - & 1.000 & $-.241^{* *}$ & $-.115^{*}$ & $-.110^{*}$ & $-.616^{* *}$ & $-.165^{* *}$ \\
\hline $\begin{array}{l}\text { Intimate } \\
\text { Partner } \\
\text { Violence }\end{array}$ & - & - & - & - & - & 1.000 & $.172^{* *}$ & $.148^{* *}$ & $.269^{* *}$ & $.169^{* *}$ \\
\hline $\begin{array}{l}\text { Decision } \\
\text { making for } \\
\text { antenatal } \\
\text { care }\end{array}$ & - & - & - & - & - & - & 1.000 & $.985^{* *}$ & $.165^{* *}$ & $.253^{* *}$ \\
\hline $\begin{array}{l}\text { Decision } \\
\text { making } \\
\text { about place } \\
\text { of } \\
\text { delivery }\end{array}$ & - & - & - & - & - & - & - & 1.000 & $.148^{* *}$ & $.274^{* *}$ \\
\hline $\begin{array}{l}\text { Decision to } \\
\text { visits } \\
\text { outdoor } \\
\text { socialize }\end{array}$ & - & - & - & - & - & - & - & - & 1.000 & $.194^{* *}$ \\
\hline $\begin{array}{l}\text { Decision } \\
\text { about } \\
\text { family } \\
\text { planning }\end{array}$ & - & - & - & - & - & - & - & - & - & 1.000 \\
\hline
\end{tabular}

**. Correlation is significant at the 0.01 level (2-tailed)

*. Correlation is significant at the 0.05 level (2-tailed).

Table no. 03 shows the person correlation between social factors and place of delivery. It is shown in the above table that social factors are importantly restrict women from access and availing the maternal health care services in the study area. The statistical result indicated that women are in subordinate position and they are restricted from mobility 
and family prefers home delivery with TBA assistance. The study further stated that men headed household is the key decision maker to decide about the health mater of her evermarried women.

\section{Discussions and Conclusions}

It is stated that social factors are determining and influencing the home delivery among ever-married women. The research hypothesis developed that social factors are responsible for poor maternal health and restricted women to home delivery. The binary logistic regression and parson correlation show the strong and significant association between social determinants and home as a place of delivery. Among the demographic variables, women age at the time of marriage, women age at the time of delivery, region and area of women residence, women and her husband education and occupation all are influencing the ever-married women place of delivery as a home. The demographic results highlighted in the present study are also highlighted in other researches conducting in developing countries. In Bangladesh Demographic and Health Survey, and Pakistan Demographic and Health Survey it is statistically shown that maternal health care services are highly influenced by women and her husband education. The studies indicated that rural and urban differences in living also influence women choice to place of delivery (Sarker, 2016; National Institute of Population Studies, 2013; Yasir, 2009). According to WHO report (2006) the poor maternal health observed among ever-married women living in rural mountains areas. The researches revealed that women delivery take place in home with the assistance of Traditional Birth Attendant. Married women are not allowed to access health facility and avail the available services (Lowe, 2016). The present study indicated that women with more than 30 years of age are staying in home and prefer home delivery. The other researches highlighted that women with more than one delivery are discouraged to visit maternal health care center for delivery services. The women delivery is attended by TBA in rural areas particularly (Mumtaz, 2014; National Institute of Population Studies, 2013).

The present study stated that women are subordinate and their health is decided by their male family members. Husbands decide women ANC, delivery and PNC. Women are confined to domestic sphere and they are not allowed to visit health facility without the consent and company of her family male or elder women member. Women are restricted from utilization of family planning methods and in developing countries a high number of unintended pregnancy are reported. Men family members defined public and private sphere. Women are socialized to stay in private domestic sphere and obey the decision of her male family members (Kadir, 2003). A study conducted in the same study area indicated that women are inferior in status and they are discouraged from visiting health facility. Women prefer to attend delivery in home with the help of TBA (Naz, 2011).

Women are not permitted to avail or use the family planning services without the approval and consent of her husband, in some case mother in law decide the use of family 
planning methods for a women (Bhutta, 2004). It is acknowledged that women mobility is one of the main factors which compel women to stay in home for delivery (Bibi, 2012).

Among the social determinants the widely prevailing situation is Intimate Partner Violence (IPV). Women are subordinate and no say in household affairs. Women are not demanding for access and utilization of health facility due to IPV. The ever-married women are facing both physical and sexual violence from her husband especially during pregnancy (Zakar, 2016; WHO, 2005). A research conducted in Pakistan indicated that IPV is one of the influencing factor toward poor maternal health among married women (Ali, 2008). It is concluded that social factors are determined the poor maternal health among ever married women.

\section{Recommendations}

The present research study recommended that government should establish mother child health care center in rural setting to encourage pregnant women delivery in these facilities. It is recommended to train traditional birth attendant who are actively engaged in home delivery to reduce maternal mortality and morbidity. The civil society organizations create awareness among married couples about the maternal health care services and complications due to delay in utilization of maternal health care from health facility. It is recommended that government should start cash transfer program for those women who deliver their child in health facility.

\section{Limitation of the Study}

The present study conducted only with quantitative research design.

\section{References}

Ali, H., Ali, A., Mahmood, Q. K., Jalal, A. \& Ali, S. R. (2016). Antenatal Care: Accessibility Issue among Pakhtun Women in Malakand, Pakistan. Methodology, vol.10, pp.362-366.

Ali, P. A. \& Gavino, M. I. B. (2008). Violence against Women in Pakistan: A Framework for Analysis. Journal-Pakistan Medical Association, vol.58:4, p.198.

Alkema, L., Chou, D., Hogan, D., Zhang, S., Moller, A. B., Gemmill, A. \& Say, L. (2016). Global, Regional and National Levels and Trends in Maternal Mortality between 1990 and 2015, with Scenario-Based Projections to 2030: A Systematic Analysis by the UN Maternal Mortality Estimation Inter-Agency Group. The Lancet, 387(10017), 462-474. 
Andersen, R. M. (1995). Revisiting the Behavioral Model and Access to Medical Care: Does it Matter? Journal of Health and Social Behavior, vol.36, pp.1-10.

Babalola, S. \& Fatusi, A. (2009). Determinants of Use of Maternal Health Services in Nigeria-Looking Beyond Individual and Household Factors. BMC Pregnancy and Childbirth, vol.9:1, p.43.

Bhatti, L. I. \& Fikree, F. F. (2002). Health-Seeking Behavior of Karachi Women with Reproductive Tract Infections. Social Science \& Medicine, vol.54:1, pp.105-117.

Bhutta, Z. A. (2004). Pakistan and the Millennium Development Goals for Health: A Case of Too Little Too Late? Journal of the College of Physicians and Surgeons Pakistan, vol.14:9, p.9.

Bhutta, Z. A., Das, J. K., Rizvi, A., Gaffey, M. F., Walker, N., Horton, S. \& Black, R. E. (2013). Evidence-Based Interventions for Improvement of Maternal and Child Nutrition: What Can Be Done and at What Cost?. The Lancet, vol.382:9890, pp.452-477.

Bibi, S., Ghaffar, S., Memon, S. \& Memon, S. (2012). Severe Acute Maternal Morbidity (SAMM) in Postpartum Period Requiring Tertiary Hospital care. Iranian Journal of Reproductive Medicine, vol.10:2, p.87.

Das, S., Bapat, U., More, N. S., Alcock, G., Joshi, W., Pantvaidya, S. \& Osrin, D. (2013). Intimate Partner Violence against Women During and After Pregnancy: A CrossSectional Study in Mumbai Slums. BMC Public Health, vol.13:1, p.817.

Ellsberg, M., Jansen, H. A., Heise, L., Watts, C. H. \& Garcia-Moreno, C. (2008). Intimate Partner Violence and Women's Physical and Mental Health in the WHO Multi-Country Study on Women's Health and Domestic Violence: An Observational Study. The Lancet, vol.371:9619, pp.1165-1172.

Fikree, F. F. \& Pasha, O. (2004). Role of Gender in Health Disparity: The South Asian Context. $B M J$, vol.328:7443, pp.823-826.

Fotso, J. C., Ezeh, A. C. \& Essendi, H. (2009). Maternal Health in Resource-Poor Urban Settings: How Does Women's Autonomy Influence the Utilization of Obstetric Care Services? Reproductive Health, vol.6:1, p.9.

Gabrysch, S. \& Campbell, O. M. (2009). Still Too Far to Walk: Literature Review of the Determinants of Delivery Service Use. BMC Pregnancy and Childbirth, vol.9:1, p.34. 
Ganle JK, Otupiri E, Parker M. \& Fitpatrick R. (2015). Socio-Cultural Barriers to Accessibility and Utilization of Maternal and Newborn Healthcare Services in Ghana after User-Fee Abolition. Int J Mater Child Health, vol.3:1, pp.1-14.

Ganle, J. K., Dery, I., Manu, A. A. \& Obeng, B. (2016). 'If I Go with Him, I Can't Talk with Other Women': Understanding Women's Resistance to and Acceptance of, Men's Involvement in Maternal and Child Healthcare in Northern Ghana. Social Science \& Medicine, vol.166, pp.195-204.

Glasier, A., Gülmezoglu, A. M., Schmid, G. P., Moreno, C. G. \& Van Look, P. F. (2006). Sexual and Reproductive Health: A Matter of Life and Death. The Lancet, vol.368:9547, pp.1595-1607.

Gupta, M. L., Aborigo, R. A., Adongo, P. B., Rominski, S., Hodgson, A., Engmann, C. M. \& Moyer, C.A. (2015). Grandmothers as Gatekeepers? The Role of Grandmothers in Influencing Health-Seeking for Mothers and Newborns in Rural Northern Ghana. Global Public Health, vol.10:9, pp.1078-1091.

Hogan, M. C., Foreman, K. J., Naghavi, M., Ahn, S. Y., Wang, M., Makela, S. M. \& Murray, C. J. (2010). Maternal Mortality for 181 Countries, 1980-2008: A Systematic Analysis of Progress towards Millennium Development Goal 5. The Lancet, vol.375:9726, pp.1609-1623.

Kadir, M. M., Fikree, F. F., Khan, A. \& Sajan, F. (2003). Do Mothers-in-Law Matter? FamilyDynamics and Fertility Decision-Making in Urban Squatter Settlements of Karachi, Pakistan. Journal of Biosocial Science, vol.35:4, pp.545-558.

Kamimura, A., Ganta, V., Myers, K. \& Thomas, T. (2014). Intimate Partner Violence and Physical and Mental Health among Women Utilizing Community Health Services in Gujarat, India. BMC Women's Health, vol.14:1, p.127.

Karlsen, S., Say, L., Souza, J. P., Hogue, C. J., Calles, D. L., Gülmezoglu, A. M. \& Raine, R. (2011). The Relationship between Maternal Education and Mortality among Women Giving Birth in Health Care Institutions: Analysis of the Cross Sectional WHO Global Survey on Maternal and Perinatal Health. BMC Public Health, vol.11:1, p.606.

Kilfoyle, K. A., Vitko, M., O'Conor, R. \& Bailey, S. C. (2016). Health Literacy and Women's Reproductive Health: A Systematic Review. Journal of Women's Health, vol.25:12, pp.1237-1255. 
King, R., Jackson, R., Dietsch, E. \& Hailemariam, A. (2015). Barriers and Facilitators to Accessing Skilled Birth Attendants in Afar Region, Ethiopia. Midwifery, vol.31:5, pp.540-546.

Lerberg, P. M., Sundby, J., Jammeh, A. \& Fretheim, A. (2014). Barriers to Skilled Birth Attendance: A Survey among Mothers in Rural Gambia. African Journal of Reproductive Health, vol.18:1, pp.35-43.

Lowe, M., Chen, D. R. \& Huang, S. L. (2016). Social and Cultural Factors Affecting Maternal Health in Rural Gambia: An Exploratory Qualitative Study. PloS One, vol.11:9.

Mahmood, N. (2002). Women's Role in Domestic Decision-Making in Pakistan: Implications for Reproductive Behaviour. The Pakistan Development Review, pp.121-148.

Mojtabai, R., Olfson, M. \& Mechanic, D. (2002). Perceived Need and Help-Seeking in Adults with Mood, Anxiety or Substance Use Disorders. Archives of General Psychiatry, vol.59:1, pp.77-84.

Mumtaz, Z. \& Salway, S. (2009). Understanding Gendered Influences on Women's Reproductive Health in Pakistan: Moving Beyond the Autonomy Paradigm. Social Science \& Medicine, vol.68:7, pp.1349-1356.

Mumtaz, Z., Salway, S., Bhatti, A., Shanner, L., Zaman, S., Laing, L. \& Ellison, G. T. (2014). Improving Maternal Health in Pakistan: Toward a Deeper Understanding of the Social Determinants of Poor Women's Access to Maternal Health Services. American Journal of Public Health, vol.104:S1, pp.S17-S24.

National Institute of Population Studies (NIPS) [Pakistan] and ICF International (2013). Pakistan Demographic and Health Survey 2012-13. Islamabad, Pakistan, and Calverton, Maryland, USA: NIPS and ICF International. Retrieved on March 24, 2019 from https://www.nips.org.pk/album_100.htm

National Institute of Population Studies (NIPS) [Pakistan] and ICF. 2019. Pakistan Demographic and Health Survey 2017-18. Islamabad, Pakistan, and Rockville, Maryland, USA: NIPS and ICF. Retrived on April 05, 2019 from https://www.nips.org.pk/study_detail.php?detail=MTc5

Naz, A., Chaudhry, H. U. R. \& Khan, W. (2011). Pakhtun Social Organization (Pakhtunwali) and Gendered Decision-Making Process in Mate Selection among Pakhtuns of District Malakand, KPK, Pakistan. Journal of Social Sciences, vol.5:2, pp.134-150. 
Nyamongo, I. K. (2002). Health Care Switching Behaviour of Malaria Patients in a Kenyan Rural Community. Social Science \& Medicine, vol.54:3, pp.377-386.

Peters, D. H., Garg, A., Bloom, G., Walker, D. G., Brieger, W. R. \& Hafizur Rahman, M. (2008). Poverty and Access to Health Care in Developing Countries. Annals of the New York Academy of Sciences, vol.1136:1, pp.161-171.

Sarfraz, M. \& Hamid, S. (2014). Challenges in Delivery of Skilled Maternal CareExperiences of Community Midwives in Pakistan. BMC Pregnancy and Childbirth, vol.14:1, p.59.

Sarker, B. K., Rahman, M., Rahman, T., Hossain, J., Reichenbach, L. \& Mitra, D. K. (2016). Reasons for Preference of Home Delivery with Traditional Birth Attendants (TBAs) in Rural Bangladesh: A Qualitative Exploration. PloS One, vol.11:1.

Stephenson, R., Baschieri, A., Clements, S., Hennink, M. \& Madise, N. (2006). Contextual Influences on the Use of Health Facilities for Childbirth in Africa. American Journal of Public Health, vol.96:1, p.84.

Suchman, E. (1965). Social Patterns of Illness and Medical Care. Journal of Health and Human Behavior, vol.6:3, pp.114-128.

Telfer, M. L., Rowley, J. T. \& Walraven, G. E. (2002). Experiences of Mothers with Antenatal, Delivery and Postpartum Care in Rural Gambia. African Journal of Reproductive Health, vol.6:1, pp.74-83.

Thaddeus, S. \& Maine, D. (1994). Too Far to Walk: Maternal Mortality in Context. Social Science \& Medicine, vol.38:8, pp.1091-1110.

Thomas, K. A. \& Taiwo, A. O. (2014). Determinants of Maternal Health Care Services Utilization in Rural Communities of Osun State, Nigeria. In South Africa International Conference on Education (p. 157).

UNFPA. (2019). State of World Population Report-2019. Retrieved on June 01, 2019 from https://www.unfpa.org/sites/default/files/pubpdf/UNFPA_PUB_2019_EN_ State_of_Worl d_Population.pdf

World Economic Forum (2019). Global Gender Gap Report-2020. Geneva, Switzerland. Retrieved from http://reports.weforum.org/global-gender-gapreport-2020/dataexplorer 
World Health Organization (WHO) (2005). Multi Country Study on Women's Health and Domestic Violence against Women'. Geneva. Available at: http://whqlibdoc.who.int/publications/2005/924159358X_eng.pdf, accessed on January 12, 2018.

Yasir, P.K., Z.B. Shereen, M. Sharma \& A.B. Zulfiqar. (2009). Maternal Health and Survival in Pakistan: Issues and Options. Journal of Obstetrics and Gynaecology, vol.31, pp.920-929.

Young, J. C. \& Young-Garro, L. Y. (1982). Variation in the Choice of Treatment in Two Mexican Communities, Social Science and Medicine, vol.16:16, pp.1453-1465.

Zakar, R., Nasrullah, M., Zakar, M. Z. \& Ali, H. (2016). The Association of Intimate Partner Violence with Unintended Pregnancy and Pregnancy Loss in Pakistan. International Journal of Gynecology \& Obstetrics, vol.133:1, pp.26-31.

Zakar, R., Zakar, M. Z. \& Kraemer, A. (2013). Men's Beliefs and Attitudes toward Intimate Partner Violence against Women in Pakistan. Violence against Women, vol.19:2, pp.246-268.

Zanconato, G., Msolomba, R., Guarenti, L. \& Franchi, M. (2006). Antenatal Care in Developing Countries: The Need for a Tailored Model. In Seminars in Fetal and Neonatal Medicine, vol.11:1, pp.15-20.

Dr. Hussain Ali is Lecturer in the Department of Sociology, Abdul Wali Khan University, Mardan, Khyber Pakhtunkhwa. 